ment of Microbiology and Immunology, Albert Einstein College of Medicine, 1300 Morris Park Avenue, Bronx, NY 10461, USA.Internet: horwitz@aecom.yu.edu

Received 23 May 1997; accepted 28 July 1997.

\author{
Yongan Li and Marshall S. \\ Horwitz \\ Albert Einstein College \\ of Medicine \\ Bronx, NY, USA
}

\section{Nonradioactive, Agarose Minigel Procedure for Telomeric Repeat Ampli- fication Protocol}

BioTechniques 23:1029-1032 (December 1997)

Telomeres, the ends of chromosomes, are composed of many kilobases of TTAGGG repeats in vertebrates. These repeats are added by the enzyme telomerase, a ribonucleoprotein DNA polymerase that synthesizes the repeats based on its RNA template. A sensitive assay combining telomerase activity and the polymerase chain reaction (PCR) known as the telomeric repeat amplification protocol (TRAP) has been developed $(6,10)$. In this assay, telomerase adds TTAGGG repeats to a telomerase substrate (TS) oligonucleotide that has no telomeric sequence; the enzyme pauses after adding each repeat, presumably to permit repositioning of its RNA template prior to synthesizing the next repeat. This generates a DNA ladder of 6-bp addition products that is then sensitively detected by polyacrylamide gel electrophoresis (PAGE) after PCR amplification (using a second $\mathrm{CX}$ oligonucleotide as reverse primer).

Telomerase activity has been detected in tumor, germ and stem cells but not in adult somatic cells. Thus, the enzyme may play a significant role in aging and in the pathogenesis of cancer
$(2,6)$. Because of this widespread interest, improvements to TRAP are continually being developed, e.g., internal standard, fluorescent TS primer and improved CX-ext primer $(7,9,12)$. We report fluorometric detection of TRAP DNA ladders by high-resolution agarose gel electrophoresis.

The human embryonic kidney (HEK) 293T cell line and the human monocytic macrophage Mono Mac 6 cell line were cultured as described (3, 5). Telomerase extracts were obtained from cells by the procedure of Kim et al. (6) with minor modifications $(1,10$, 11). Cells were counted, harvested and treated with ice-cold TRAP lysis buffer at $10^{6}$ cells $/ 100 \mu \mathrm{L}$ buffer. The TRAP lysis buffer contained $0.5 \%$ 3-[(3-cholamidopropyl)-dimethyl-ammonio]-1propanesulfonate (CHAPS), $50 \mathrm{mM}$ Tris- $\mathrm{HCl}, \mathrm{pH} 7.4,5 \mathrm{mM} \mathrm{MgCl}_{2}, 5 \mathrm{mM}$ EGTA, $25 \mathrm{mM}$ 2-mercaptoethanol, 1 $\mathrm{ng} / \mathrm{mL}$ leupeptin and $50 \%$ glycerol in diethyl pyrocarbonate (DEPC)-treated water. The lysate was kept on ice for 30 $\mathrm{min}$ and then centrifuged at $16000 \times \mathrm{g}$ for $20 \mathrm{~min}$ at $4^{\circ} \mathrm{C}$ in a Model 5415 Eppendorf $^{\circledR}$ Microcentrifuge (Brinkmann Instruments, Westbury, NY, USA). Afterwards, $80 \mu \mathrm{L}$ of supernatant were collected, flash-frozen in liquid nitrogen and stored at $-75^{\circ} \mathrm{C}$ until used.

Detection of telomerase activity from cell extracts was performed in a two-step process: $(i)$ telomerase-mediated extension of the TS nucleotide and (ii) PCR amplification of the resultant product with both TS and the reverse CX primers $(1,10,12)$. The oligonucleotides TS (5'-AATCCGTCGAGCAGAGTT-3') and CX (5'-CCCTTACCCTTACCCTTACCCTAA-3') (both from BioSynthesis, Lewisville, TX, USA) were each dissolved in DEPC-treated water at $0.1 \mu \mathrm{g} / \mu \mathrm{L}$. Each thin-wall PCR tube contained $20 \mu \mathrm{L}$ of a reaction mixture that included $16.5 \mu \mathrm{L}$ of TRAP reaction buffer (20 mM Tris-HCl, pH 8.2, $63 \mathrm{mM} \mathrm{KCl}, 1.5 \mathrm{mM} \mathrm{MgCl} 2,1 \mathrm{mM}$ EGTA, $0.1 \mathrm{mg} / \mathrm{mL} 1 \times$ bovine serum albumin [BSA] and $0.05 \%$ Tween ${ }^{\circledR} 20$ ), $1 \mu \mathrm{L}$ of TS $(0.1 \mu \mathrm{g}), 0.5 \mu \mathrm{L}$ of dNTPs (10 mM stock) and $2 \mu \mathrm{L}$ cell extract (from 1000 cells). The telomerase extension reaction was completed in a Model DB 66925 Temp.Tronic ${ }^{\circledR}$ Thermal Cycler (Barnstead/Thermolyne, 


\section{Benchmarks}

Dubuque, IA, USA) after $30 \mathrm{~min}$ incubation at $25^{\circ} \mathrm{C}$; the temperature was then raised to $90^{\circ} \mathrm{C}$ for 2 min to inactivate the telomerase. During this time, 5 $\mu \mathrm{L}$ of PCR mixture (containing $3.5 \mu \mathrm{L}$ of TRAP reaction buffer, $1 \mu \mathrm{L}$ of $\mathrm{CX}$ $[0.1 \mu \mathrm{g}]$ and $0.5 \mu \mathrm{L}$ of Taq DNA polymerase [2.5 U]) were added to each tube together with $30 \mu \mathrm{L}$ of mineral oil for hot-start PCR. A 34-cycle PCR was performed at $94^{\circ} \mathrm{C}$ for $30 \mathrm{~s}, 50^{\circ} \mathrm{C}$ for 30 $\mathrm{s}$ and $72^{\circ} \mathrm{C}$ for $45 \mathrm{~s}$, with a final extension at $72^{\circ} \mathrm{C}$ for 2 min. TRAP products were analyzed by high-resolution agarose gel electrophoresis.

For gel analysis, a horizontal minigel apparatus (Mini-Sub ${ }^{\circledR}$ Electrophoresis Cell; Bio-Rad, Hercules, CA, USA) and the TBE buffer system were used. The gel was composed of $4.5 \%$ MetaPhor ${ }^{\circledR}$ agarose (FMC BioProducts, Rockland, ME, USA). For a 3$\mathrm{mm}$ gel, $1.125 \mathrm{~g}$ agarose were stirred in $26 \mathrm{~mL}$ TBE in a beaker, weighed and dissolved using a microwave oven (with care not to cause spilling) and reweighed (for loss during microwave treatment), and warm water was added to obtain the original weight before cooling and pouring. After setting at room temperature, the gel was chilled for $30 \mathrm{~min}$ at $4^{\circ} \mathrm{C}$ before use. For each lane, $21 \mu \mathrm{L}(18 \mu \mathrm{L}$ TRAP products and $3 \mu \mathrm{L}$ gel-loading buffer [6× dye: $0.25 \%$ bromophenol blue, $0.25 \%$ xylene cyanol and $15 \%$ Ficoll $^{\circledR}$ Type 400 in water]) were loaded. For molecular weight standard, $0.5 \mu \mathrm{L}$ of the 123-bp ladder (Life Technologies, Gaithersburg, MD, USA) was also loaded onto a separate gel lane. The agarose gel was run at $100 \mathrm{~V}$ for $2 \mathrm{~h}$ in a $4^{\circ} \mathrm{C}$ coldroom. After gel electrophoresis, DNA bands in the gel were detected after a 30-min staining with SYBR ${ }^{\circledR}$ Green I fluorescent dye (FMC BioProducts or Molecular Probes, Eugene, OR, USA) in a tinfoil-covered polypropylene contain- er with gentle shaking ( $5 \mu \mathrm{L}$ dye in 50 $\mathrm{mL}$ TBE, $10000 \times$ stock). The bands were seen under a Foto/Prep I UV Transilluminator (Fotodyne, Hartland, WI, USA), and the stained agarose gel was analyzed using the Storm ${ }^{\mathrm{TM}}$ Fluorescence Scanning System (Molecular Dynamics, Sunnyvale, CA, USA) (4, 10). Although fluorescence scanning was used here, it should be noted that photographic documentation is also possible with the UV transilluminator and a SYBR Green gel stain photographic filter.

By this approach, we were successful in using an agarose minigel system to visualize the TRAP DNA ladders (Figure 1). The reaction was specific because the ladder was absent if the reverse $C X$ primer had been omitted (Figure 1A, lane 2) or if the cell extract had been pretreated with RNase [Figure $1 \mathrm{~A}$, lanes 4 and 6 , and $1 \mathrm{~B}$, lane $4 ; 5$ $\mu \mathrm{L}$ of cell extract were incubated with 


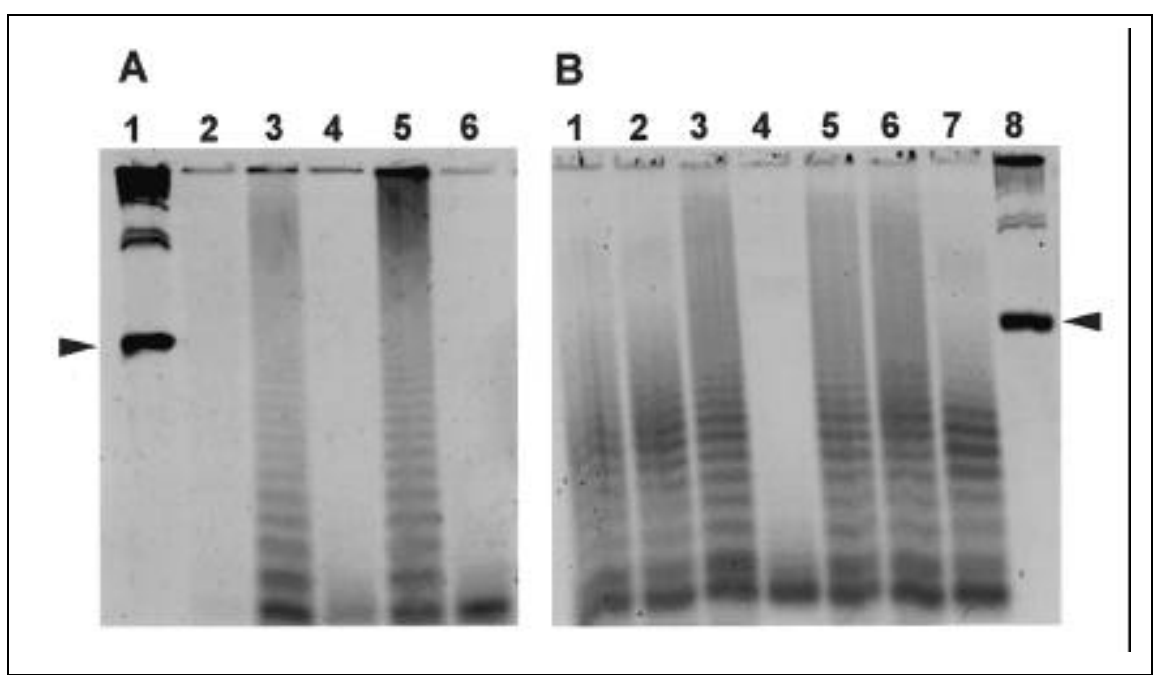

Figure 1. Analysis of TRAP products after 4.5\% MetaPhor agarose gel electrophoresis and SYBR Green I staining. (A) Lane 1: 123-bp marker; lane 2: extract from $10000293 \mathrm{~T}$ cells, CX primer omitted; lane 3: extract as in lane 2, with all components; lane 4: extract as in lane 2, after RNase treatment; lane 5: extract from $1000293 \mathrm{~T}$ cells; lane 6: extract as in lane 5, after RNase treatment. (B) Lanes 1-6: extract from 4000 293T cells; lane 7: extract from 8000 Mono Mac 6 cells. Lane 1: TRAP buffer with RNase inhibitor and T4 gene 32 protein; lane 2: TRAP buffer with T4 gene 32 protein; lane 3: TRAP buffer alone; lane 4: as in lane 3 but cell extract pretreated with RNase; lane 5: TRAP buffer without BSA; lanes 6 and 7: TRAP buffer with $1 \mathrm{mg} / \mathrm{mL}$ BSA; lane 8: 123-bp marker.
$1 \mu \mathrm{L}$ of $1-\mathrm{mg} / \mathrm{mL}$ RNase $\mathrm{A}$ at $37^{\circ} \mathrm{C}$ for $20 \mathrm{~min}$, and then $2 \mu \mathrm{L}$ of the product were used for the reaction; however, non-telomerase-mediated DNA bands were still seen, as also observed by others $(10,11)]$. Under the TBE electrophoretic condition, the dye xylene cyanol moved to about $1 / 3$ and bromophenol blue to about $2 / 3$ down the $4.5 \%$ MetaPhor agarose gel. Since the majority of the discernible DNA ladder was below the 123-bp band (arrow, Figure $1 \mathrm{~A}$, lane 1 , and $1 \mathrm{~B}$, lane 8 ), the observed 6-bp DNA ladders seemed to distribute mostly between 40 and about $150 \mathrm{bp}$ in this gel system. Similar to this finding with the high-resolution agarose gel, a 3\% MetaPhor agarose gel has previously been used to detect a 4-bp deletion (from 170 to $166 \mathrm{bp}$ ) in prenatal diagnosis of $\beta$ thalassemia in some Chinese patients (8). Because acrylamide monomers are known to be toxic, the use of agarose may be more 
advantageous than polyacrylamide.

Attempts were made to streamline the TRAP conditions and components. For the HEK 293T cells, an extract from 1000 cells gave a better DNA ladder than one from 10000 cells (Figure $1 \mathrm{~A}$, lane 5 vs. 3 ). Individual components were also tested, and several were found not to be essential. Since telomerase is a ribonucleoprotein and we were concerned with RNase contamination, an RNase inhibitor (30 U RNasin ${ }^{\circledR}$; Promega, Madison, WI, USA) was initially included. This was not needed as long as DEPC-treated water was used (Figure 1B, lane 1 vs. 3). The use of T4 gene 32 protein $(2.5 \mu \mathrm{g}$; Boehringer Mannheim, Indianapolis, IN, USA) was also not needed (Figure 1B, lane 2 vs. 3). BSA had no effect (Figure 1B, lanes 1-4, $1 \times \mathrm{BSA}$; lane 5, no BSA; lanes 6 and 7, 10× BSA). In addition to HEK 293T cells, others such as Mono Mac 6 cells (Figure 1B, lane 7) and human prostate $\mathrm{LNCaP}$ cells (data not shown) all showed the 6-bp DNA ladders in agarose minigels after staining. Furthermore, we have found that DNA ladder patterns were also observed when using the modified CX-ext primer (5'-GTGCCCTTACCCTTACCCTTACCCTAA- $3^{\prime}$ ), one that may be free of some TRAP artifacts (7). Thus, it is possible to combine CX-ext, MetaPhor agarose minigel and SYBR Green I stain in a nonradioactive analysis of TRAP products.

We used the fluorescent dye SYBR Green I for the staining of TRAP products in agarose gels. Previously, the stain had been used to visualize TRAP DNA ladders after PAGE (10). Thus, we are in agreement on the suitability of using fluorescent DNA dye for TRAP instead of radioisotopes. This minimizes potential health hazards and decreases the amount of radioactive waste materials.

In summary, we have reported a convenient telomerase assay that can be done completely, from cell to gel, within a day. To our knowledge, this is the first report on the use of high-resolution agarose gel electrophoresis for the analysis of DNA products from TRAP.

\section{REFERENCES}

1.Albanell, J., W. Han, B. Mellado, R. Gunawardane, H.I. Scher, E. Dmitrovsky and M.A. Moore. 1996. Telomerase activity is repressed during differentiation of maturationsensitive but not resistant human tumor cell lines. Cancer Res. 56:1503-1508.

2.Autexier, C. and C.W. Greider. 1996. Telomerase and cancer: revisiting the telomere hypothesis. Trends Biochem. Sci. 21:387-391.

3.Chan, M.M. 1995. Inhibition of tumor necrosis factor by curcumin, a phytochemical. Biochem. Pharmacol. 49:1551-1556.

4.Holt, S.E., W.E. Wright and J.W. Shay. 1996. Regulation of telomerase activity in immortal cell lines. Mol. Cell. Biol. 16:29322939.

5.Kiledjian, M., X. Wang and S.A. Liebhaber. 1995. Identification of two KH domain proteins in the alpha-globin mRNP stability complex. EMBO J. 14:4357-4364.

6.Kim, N.W., M.A. Piatyszek, K.R. Prowse, C.B. Harley, M.D. West, P.L.C. Ho, G.M. Coviello, W.E. Wright, S.L. Weinrich and J.W. Shay. 1994. Specific association of hu- man telomerase activity with immortal cells and cancer. Science 266:2011-2015.

7.Krupp, G., K. Kuhne, S. Tamm, W. Klapper, K. Heidorn, A. Rott and R. Parwaresch. 1997. Molecular basis of artifacts in the detection of telomerase activity and a modified primer for a more robust 'TRAP' assay. Nucleic Acids Res. 25:919-921.

8.Law, H.Y., J. Ong, C.S. Yoon, H. Cheng, C.L. Tan and I. Ng. 1994. Rapid antenatal diagnosis of beta-thalassemia in Chinese caused by the common 4-bp deletion in codons $41 / 42$ using high-resolution agarose gel electrophoresis and heteroduplex detection. Biochem. Med. Metab. Biol. 53:149-151.

9.Ohyashiki, J.H., K. Ohyashiki, T. Sano and K. Toyama. 1996. Non-radioisotopic and semi-quantitative procedure for terminal repeat amplification protocol. Jpn. J. Cancer Res. 87:329-331.

10.Piatyszek, M.A., N.W. Kim, S.L. Weinrich, K. Hiyama, E. Hiyama, W.E. Wright and J.W. Shay. 1995. Detection of telomerase activity in human cells and tumors by a telomeric repeat amplification protocol (TRAP). Methods Cell Sci. 17:1-15.

11.Strahl, C. and E. Blackburn. 1996. Effects of reverse transcriptase inhibitors on telomere length and telomerase activity in two immortalized human cell lines. Mol. Cell. Biol. 16:53-65.

12.Wright, W.E., J.W. Shay and M.A. Piatyszek. 1995. Modifications of a telomeric repeat amplification protocol (TRAP) result in increased reliability, linearity and sensitivity. Nucleic Acids Res. 23:3794-3795.

We thank Drs. M. Kiledjian and H.W.L. Ziegler-Heitbrock for cell lines, Dr. Robert Herman for comments on the manuscript and Mr. Jonathan V. Mensch (FMC BioProducts) for initial samples of MetaPhor agarose. This work was supported in part by a grant from the American Institute for Cancer Research to M.M.-Y.C. Address correspondence to Dunne Fong, C226 Nelson Biological Laboratories, Rutgers University, Piscataway, NJ 08855-1059, USA. Internet:fong@biology.rutgers.edu

Received 12 June 1997; accepted 19 August 1997.

Dunne Fong1, James P. Burke ${ }^{2}$ and Marion Man-Ying Chan ${ }^{1,2}$ ${ }^{1}$ Rutgers, The State University of New Jersey

Piscataway, NJ

${ }^{2}$ Pennsylvania College of

Podiatric Medicine

Philadelphia, PA, USA 